University of Nebraska - Lincoln

DigitalCommons@University of Nebraska - Lincoln

Faculty Publications: Department of Teaching, Department of Teaching, Learning and Teacher Learning and Teacher Education

Education

February 2001

\title{
Theorizing the Sojourner Student (With a Sketch of Appropriate School Responsiveness)
}

\author{
Edmund T. Hamann \\ University of Nebraska - Lincoln, ehamann2@unl.edu
}

Follow this and additional works at: https://digitalcommons.unl.edu/teachlearnfacpub

Part of the Teacher Education and Professional Development Commons

Hamann, Edmund T., "Theorizing the Sojourner Student (With a Sketch of Appropriate School Responsiveness)" (2001). Faculty Publications: Department of Teaching, Learning and Teacher Education. 73.

https://digitalcommons.unl.edu/teachlearnfacpub/73

This Article is brought to you for free and open access by the Department of Teaching, Learning and Teacher Education at DigitalCommons@University of Nebraska - Lincoln. It has been accepted for inclusion in Faculty Publications: Department of Teaching, Learning and Teacher Education by an authorized administrator of DigitalCommons@University of Nebraska - Lincoln. 


\title{
Theorizing the Sojourner Student (With a Sketch of Appropriate School Responsiveness)
}

\author{
Edmund T. Hamann
}

\begin{abstract}
In response to inadequate local resources (as subjectively defined) in both sending and receiving communities and in response to related local racial/ethnic discriminations, transnational families engage in transnational economic, cultural, and psychological risk-minimization strategies - the substance of a "transnationalism from below" (Smith and Guarnizo 1998) — that are discordant with the enculturative presumptions of schooling. A special type of transnational migrant described here-the sojourner student-is thus vulnerable not only to (a) the original migration-inducing conditions and (b) the limitations of opportunity in the receiving community, but also (c) to the contradictions between their response strategy and the standard suppositions of schooling. This vulnerability, however, could be ameliorated rather than exacerbated by schooling, if educators were sufficiently responsive to sojourner students' circumstances.
\end{abstract}

\section{Towards a New Typology}

In keeping with the longstanding anthropological tradition of theorizing typologies to mark similarities and difference (Brettell 2000:99), including typologies of migrants and migration (e.g., Gonzalez 1961), this paper proposes a new category — the sojourner student—who should be added to taxonomies of transnational migrants and of students. Sojourner students' two defining characteristics are their vulnerability to dislocation and their transnational backgrounds, though additional modifiers like poor, Latinola, limited-English-proficient, and undocumented also often apply to sojourner students, at least in the U.S. Again with reference to the U.S., sojourner students are unrecognized and ill served by the common praxis and organization of schools. As with schooling elsewhere, that praxis and organization are undergirded by assimilationist and citizenship-developing presumptions (Ty- 
ack 1974; Olneck 1995; Hornberger 2000; Cohen 2000) that poorly align with sojourner students' life circumstance and worldview.

A quick review of contemporary studies of transnationalism (the next section) reveals why sojourner students and the households they are part of are vulnerable to dislocation. The same review highlights the incompleteness and sometime inaccuracy of conceptualizing international migration strictly in terms of immigration and emigration-well after initially joining a migration flow, a persistent portion of international migrants, including some school-age migrants, seem still to be mobile, still to be binationally tied, and still not to be fully settled in their new environs. This is partly because of the cultural and material conditions encountered in both sending and receiving communities. However, the emerging concept of "transnationalism from below" (Smith and Guarnizo 1998) also helps explain this transnational flux by reminding us of the agency and active decision-making engaged in by the millions of families and individuals who cross (and often recross) international (and intra-national) borders as they balance aspiration, need, risk, affiliation, responsibility, and awareness of self and circumstance. Massey and others have referred to this semi-permanent transnationalism as a "culture of migration" (Brettell and Hollifield 2000: 16).

The strategic actions and related beliefs that make up "transnationalism from below," however, often conflict with the strategies and assimilative presumptions that commonly undergird U.S. schooling. Lamphere (1992) and Goode, et al. (1992) refer to schools as "mediating institutions" at which macro-dynamics like transnational migration, economic stratification, and group boundary-marking processes (Barth 1969) are enacted and endowed with various meanings at the individual and community levels. At U.S. schools, for sojourner students, that mediation is typically manifest as a hybrid of invisibility and dismissal. Adrienne Rich (in Rosaldo 1989:ix) has written, "When someone with the authority of a teacher, say, describes the world and you are not in it, there is a moment of psychic disequilibrium, as if you looked in the mirror and saw nothing." By denying sojourner students' very presence (by labeling them under other categories) and/or by dismissing their obligation to non-permanent newcomers, schools put sojourner students at an academic disadvantage.

Anthropologists of education describing efficacious schooling emphasize that schools need to recognize and build from students' varying "funds of knowledge" (Moll et al. 1992, Gonzalez et al. 1995) - i.e., the knowledge acquired through their personal experience and family and cultural heritage. Absent recognition of the fundamental salience of sojourner status to some 
students' lives, both educational policymakers and educators are poorly positioned to assure such responsiveness. The third section highlights this mismatch.

This paper responds to Clemens' call for further investigation of "how schools do or do not aid students in making transitions to other forms of social activity" (1999:117). Pursuant to Forman (1994), I subscribe to the tenet that anthropological inquiry should inform problem solving and improvement of, in this case, school practice, hence the final section which sketches what a sojourner-responsive pedagogy might look like. ${ }^{1}$ In addition to the quantities of anthropological scholarship reviewed (including some of my own fieldwork in Georgia and Kansas), I borrow Sol Tax' old emphasis on contributing to others' knowledge of the choices available to them (Hinshaw 1979). In this instance, my society-the U.S. - seems largely unaware of the choices it has made that make some students sojourner students and that assure such status connotes academic disadvantage.

I also share anthropology's "assumption[s] that outcomes for people who move are shaped by their social, cultural, and gendered locations and that migrants themselves are agents in their behavior, interpreting and constructing within the constraints of structure" (Brettell and Hollifield 2000:4). The exercise of agency is implicit in transnational movement (though parents' agency more than children's), while the comparatively reduced agency transnational students have in relation to school policy (except to react) is an example of the salience of constraining structures.

To date, the struggles faced by sojourner students and those who attempt to teach them have only been hinted at in the research literature-in studies of immigrant students, migrant students, English language learners, Latino students, and so on. Though all of these labels refer in overlapping fashion to some sojourner students, they are not synonyms. Sojourner students are not necessarily immigrants, at least not in the permanent sense implied by that term. Nor are they necessarily migrant students, referring specifically to those eligible for enrollment in the U.S. government-funded, compensatory, Migrant Education program. ${ }^{2}$ All sojourner students do come from a linguistic background that is distinct from that primarily championed at school (i.e., distinct from standard American English in the U.S.), but not all English language learners are sojourners. Not all Latino students are sojourners (most are not), nor are all sojourners Latino.

Still, using these proxy labels, one can see potent hints of sojourner students' academic vulnerability. According to the National Center for Educational Statistics (1997), in 1995 those who had "difficulty speaking Eng- 
lish" constituted 5.3 percent of the U.S. population of 16- to 24-year-olds, but constituted 44.3 percent of the dropouts. Though mobility is also an imperfect descriptor of sojourner status (measuring actual movement instead of the social and psychological constructions of vulnerability to movement), the U.S. General Accounting Office (1994) found that student mobility was higher among Latino, black, Native American, and poor children than among white, Asian, and middle- and high-income children. Garcia (1998: vii) has noted that "Only $10 \%$ of non-Hispanic White students leave school without a diploma, whereas . . . 33\% of Hispanics . . . and 66\% of immigrant students drop out of school." Garcia continued: "Confronted with this dismal reality, administrators, teachers, parents, and policymakers urge each other to do something different. Changes in standard educational strategies are needed, but will be meaningless unless these students are thought about differently." Of course, my goal too is to promote thinking about these students differently, starting with accurate labeling.

My proof of the existence of sojourner students is largely derived here as a synthesis of research theory, from a linkage between transnational migration theory and educational theory, with the analysis of both weighted to an anthropological perspective. However, there is empirical proof as well; Trueba (1999), Hagan (1994) and Garcia (1999) all offer examples of sojourner students. A review of the literature on transnational migration suggests that sojourner students are a common presence in schools, as the dynamics that together make sojourner students are common. These dynamics are described by theories as broadly different as the notions of "inauthentic citizenship" (Joseph 1999) and "dual system theory" (Piore 1979, Gutiérrez 1999).

Further proof of the presence of sojourner students and of their invisibility can also be derived from my dissertation research (Hamann 1999a). For that study, I examined the creation of a multi-faceted, binational partnership that was intended to help two adjacent Georgia school districts better negotiate the continuing rapid growth in their enrollments of Mexican-origin students. Both districts were atypically responsive-recruiting bilingual teachers from a Mexican university, sending their teachers to the same Mexican university for month long summer training session, and so on-but in both districts sojourner students were generally invisible to the promoters of the partnership and to the general public. A plan to accommodate those who might not be staying was never broached even though high student mobility rates and Latino parent interview data both suggested that not all newcomer students were staying (Hernández-León and Zuñiga 2000). Rather, as I have noted elsewhere (1999b), Anglo supporters of the bina- 
tional partnership consistently solicited support for the partnership using a they-are-here-permanently-thus-we-must-act discourse. ${ }^{3}$ Because the diagnosis was that the newcomers were permanent settlers, a school strategy based on how to help the newcomers assimilate was deemed both appropriate and complete.

Several questions ultimately guide this paper: What can school teach to help students who are engaged in transnationalism from below? What can it teach to those who need to negotiate multiple community environments (in two countries and at least two locales)? Thinking of the sojourner students who were in the schools in my Georgia dissertation site, what can it teach to help students who will negotiate the "secondary sector" (Piore 1979; Gutiérrez 1999) or "bottom" (Spener 1988) of the U.S. economy (and perhaps low-opportunity sectors of the Mexican economy)? What should schools teach those who face the additional challenge of lacking legal work authorization? How can a curriculum for sojourner students be effectively delivered in the face of such students' high mobility, their disjointed school experiences, and their tentative attachment to place? How can/should schools help students who need multiple cultural literacies? To understand why literacies is a plural in this last question, Guerra's plural and context-dependent definition of literacy helps:

It is clear that an individual's literacies vary according to the personal and social circumstances of his or her life, so everyone is considered literate in certain situations and not in others. The goal from this perspective, is not to master a particular form of literacy, but to develop one's ability to engage in a variety of social practices that require us to operate in a plethora of settings and genres to fulfill different needs and goals. In academic terms, it means that identifying and understanding a set of assumed universal standards is not only no longer possible, but no longer meaningful. [1998:58]

Guerra's (1998) emphasis on the idea of a transnational communityi.e., a community that can only be geographically-defined with reference to more than one place in more than one nation state- suggests a final useful question: What education is most appropriate for those who live in transnational communities? 


\section{Refining the Sojourner Student Model: The Challenges of Transnationalism}

While the term student is pretty straightforward (in this case referring to those who attend or are eligible to attend primary or secondary school),${ }^{4}$ I take the term sojourner from Hackenberg's (1995:248) referral to the sojourner versus settler debate that has been ongoing in international migration research circles for several decades (e.g., Chavez 1988). That debate focuses on when/whether transnational newcomers to a receiving community should be considered permanent members of their new community. By emphasizing the term sojourner I am not rejecting the stand taken by many on the settlement side-i.e., that many newcomers are settling as permanent members of their new locales. (See González Baker, et al. [1999], Massey, et al. [1987: 1791, and Gutiérrez [1999:321].) But I do want to assert that not all newcomers are permanent settlers. As importantly, not even all who end up staying permanently "imagine" themselves as permanent settlers (Anderson 1991, Chavez 1994). For this latter group an educational strategy that presumes permanence is off-putting.

The sojourner population is composed of the not necessarily permanent. Sojourners, as a product of the vicissitudes of the locale where they are living and/or their own will, are not deeply attached to that place and could readily move or be dislocated. Often sojourners' "life worlds are neither 'here' nor 'there' but at once both 'here' and 'there"' (Smith 1994: 17, italics original).

Sojourner students and other members of their households fit within what Smith and Guarnizo (1998: 18) call "the new transnational working class." That transnational working class lives out a transnationalism from below. Transnationalism from below refers to the active decision-making by members of economically vulnerable households to reduce their vulnerability by enacting strategies that take advantage of legal, economic, and cultural resources in more than one nation state. Transnationalism from below also indexes the advance of globalizing economic forces and the changes in communicative, transportation, and legal technologies that together are contextual features that shape transnational migrants' choices and cosmologies.

As Appadurai (1996) has noted, the opportunity for immigrant newcomers to maintain links with their sending countries is unprecedented at the end of the 20th century. One can think of the thousand plus Mexicans, noted by Ainslie (1999), who return to Tehuixtla (normally a village of 200) for the Christmas season and who send remittances there year-round. One can also think of the Mexican newcomers in my Georgia research site who 
read extensively about Latin American concerns in Georgia-produced, Spanish-language newspapers, who access Latin America-produced television programs on their standard cable television package, and who often take advantage of various governmental services provided by the Mexican Consulate in Atlanta (Hamann 1999a).

Taking advantage of the resources available on both sides of the border is more complicated if the receiving community is a significant distance from the border. Nonetheless, the practice of maintaining not just financial and communicative links, but physical ones is often still operative. When I first made entree to my Georgia research site as a grant writer, many local educators complained about the lengthy absences of newcomer Latino students, particularly around Christmas, because of whole families' return visits to Mexico.

Appadurai (1996:4) offers examples of Turkish "guest workers" in Germany watching Turkish films and Pakistani cab drivers in Chicago listening to cassettes of sermons recorded in mosques in Pakistan and Iran to assert that the contemporary explosion of mass media and the simultaneous acceleration of historic processes of transnational migration together have created new "diasporic public spheres." He adds that such deterritorialized public spheres confound theories that depend on the continued salience of the nation-state as the key arbiter of important social changes. It does not seem to be too much of a stretch to apply Appadurai's description to what Limón (1998), borrowing from Paredes, calls "Greater Mexico" (i.e., the deterritorialized public sphere that includes all portions of North America where Mexican-origin people live).

But Appadurai's (1996) perspective contrasts with that of Smith and Guarnizo who focus on "discourses of identity" that are centered around "group loyalties and affiliations fostered by localities and by the state" (1998:22). Smith and Guarnizo (1998:9) point out that in studies of transnationalism "it is important to recall that the agents of 'receiving states' remain relevant actors." Schools are one such agent. Thus emerges a central tension, the conflict between obviously state-tied entities (i.e., schools) and obviously transnational processes and phenomena (like transnational migration and the deterritorialization of the public sphere). In this conflict, schools retain their power to convey or deny access and opportunity.

\section{Transnationalism from Below, Secondary Sector Employment, and Household Vulnerability}

There is a distinction between the substantial acculturative challenges encountered by immigrant students settling in a new community and the even 
more chaotic challenges encountered by students who are or whose parents are sojourner laborers and who are not clearly rooted in either a sending or a receiving community. Sojourner students face extra acculturative challenges; they need not only to learn how to negotiate this new place (i.e., the community surrounding their present school), but more fundamentally any new place, as the prospect looms that they will sooner or later be headed someplace else. Sojourner students also need to retain and enhance their capacities to negotiate the old places (i.e., the places they have previously lived and, given the data on circular and repeat migration, places where they may well live again). Their challenge is to develop meta-cognitive skills regarding negotiation of multiple places and multiple cultures.

Though his article about the education of Mexican immigrant and transnational children does not explicitly consider the typology of a sojourner student, Trueba (1999:267) asks a number of questions that can highlight some of the educational dilemmas faced by the Mexico-linked portion of the sojourner student population: (a) "What are the fundamental changes in values and lifestyle, and what are the consequences of such changes for both the survival and prosperity of immigrants in the United states and their temporary presence in Mexico?" (b) "How do children adjust in Mexico and back in Mexican schools?" (c) "For those who return to Mexico for extended periods of time, what is the impact of the socioeconomic, political, and cultural changes they have experienced as they engage in daily life in Mexico?”

Acknowledging transnationalism from below's emphasis on the agency of ordinary people reminds us that sojourner students, or at least the adults in their household, choose to stay, choose to relocate, and/or choose to gather information about opportunities and survival strategies. In so doing, transnational families may challenge the social hierarchy. However, sojourner students and their families exercise agency subject to the often substantial constraints of daily survival needs, structural impediments, and the cultural lenses through which they understand their circumstances and options. From below also makes a realistic statement about power, as those acting from below have less power than those acting upon them from above. Those making choices "from below" confront more limited opportunity horizons and more pressing immediate needs. This makes long-term planning difficult.

Sojourner students and/or the households they are part of have been dislocated by the global spread of capitalism. Moreover, there are particular racialized dimensions to seeking work as a minority newcomer to a receiving community (Goldring 1996, 1998). Thus, displacement can remain a circumstantial reality for many as a long-term condition of global capitalism 
and not just in locations where global capitalism is newly penetrating, but also in the developed-world sites receiving newcomers. Hackenberg and $\mathrm{Ku}-$ kulka (1995) have documented both the limited duration of employment and the somewhat longer stays in the region of newcomer laborers working in Kansas meatpacking plants. In their case study, employers use a replacement labor strategy, offering minimal advancement opportunities and giving little weight to seniority. Workers seeking improved wages, work conditions, etc. are easily replaced with new employees.

During my Masters thesis fieldwork in central Kansas (Hamann 1995), I remember shadowing a bilingual paraprofessional (school aide) as he made a home visit to inquire why a student enrolled several weeks earlier in the local elementary school had not been coming to school over the last few days. The father explained to the paraprofessional that he was unemployed and kept his daughter home to help him as an interpreter and translator as he sought new work. (His daughter was 11 or 12 years old.) Without new work, the family would need to move again. That family's circumstances square with Hackenberg and Kukulka's (1995) case study. The daughter was a sojourner student.

Often, there are economic explanations for sojourner students' rootlessness. Adults in sojourner student households (and sometimes sojourner students themselves) have high labor force participation rates, but the jobs they have access to are almost always low status and vulnerable to changes in the economic cycle. Cornelius (1989:4) observed that, "[Immigrant labor] can be brought on board quickly when needed in periods of peak product or service demand and disposed of just as easily when demand slackens." Spener wrote (1988:138) "A primary role for immigrants in modern, postindustrial countries is to serve as a buffer between the domestic population, specifically the native-born working class, and the effects of periodic downturns in the economy."

Both Cornelius and Spener were describing manifestations of what dual system theorists call the secondary sector of the economy (Piore 1979; Gutiérrez 1999). Dual system theory posits that in developed countries (e.g., the United States) the economy can by divided into two sectors, the primary sector and the secondary sector. In the primary sector, jobs are salaried and stable, and an employee's educational status correlates with the rank and compensation of his/her job position. Because capitalist economies are inherently cyclic, the primary sector has created an expendable, secondary sector which can be expanded in boom times and reduced during busts. Jobs in the secondary sector can be reasonably well paid (they 
were in my research site), but offer little job security. Moreover, in the secondary sector an employee's school attainment does not correlate with his/ her wage, job status, or job security; it does not matter if a worker has only completed primaria (i.e., sixth grade in Mexico) or whether they have attended college. The secondary sector protects the primary sector from all but the sharpest economic fluctuations.

Conceding that the bifurcation in dual system theory can be blunt and simplistic, ${ }^{5}$ considering newcomer household's frequent access only to the secondary sector clarifies why many sojourner student households are vulnerable and displaceable. Burawoy (1983) notes that the absence of differentiated skill levels and a refined division of labor in the secondary labor market can lead to management's encouragement of turnover and frequent worker replacement. This firing and replacing is enabled if a high-turnover job category is "ethnically-typed" (Tienda 1989)—i.e., most workers for a particular job share an ethnic background-and if transnational labor recruiting networks promise the arrival of new workers of the same ethnic origin. ${ }^{6}$

Furthermore, if seniority (and its relatively higher wages) are a disincentive for a worker to leave, but a position is de-skilled, then an employer has an incentive to fire or push out those accruing seniority as long as there are replacements available who will work for lower introductory wages. By tying employers to sources of new labor, informal, often ethnically homogeneous transnational labor recruiting networks can facilitate such a management policy. In this way, the maintenance of transnational social networks that facilitate job acquisition and reduce household economic vulnerability also contributes to hegemonic (i.e., stratified) social reproduction.

Stark (1991) has suggested risk-minimization is a main goal for extended families involved in transnational migration. The case studies of Pugach (1998), Ainslie (1999), Valdés (1996), Guerra (1998), and Hagan (1994) all show evidence consistent with this theory. Put simply, Stark suggests that because of the high vulnerability of economic niches available to transnationals (in their home country or as migrants) an extended family can benefit by spreading and thus reducing its risk. This strategy means that it is more likely that some family members will be in temporarily prosperous enough circumstances (e.g., landing a job at a carpet mill) to support other family members. The strategy depends on the continued salience of family or even fictive kin ties of those within the network (ensuring the intra-network distribution of resources). Those in sending communities dependent on remittances have an incentive to assure that those who have transnationally migrated still feel a connection to home. 
Transnational Infrastructure, Transnational Movement, and Vulnerability to Displacement

Smith and Guarnizo (1998:24) note that transnational transformation includes global political transformations like the rise of cross-national institutional networks (e.g., the Mexican federal government's Mexicanos en El Extranjero program). Cross-national institutional networks complement informal social networks and help sojourner families sustain loyalties and logistic ties to their countries of origin and to reduce their risk in the receiving country (e.g., the U.S.). Representatives from Mexican consulate office in Atlanta were frequent presences at my Georgia research site, and it was even more common for Mexican newcomers to head to Atlanta for Mexican government services. In 1999, in a measure that de facto reduced the economic risk of the transnational movement of undocumented migrant laborers and their families, Mexican consular officials in Georgia appealed to a basic right of just compensation when they advocated to assure that undocumented laborers were not denied payment for work rendered. However modestly, such advocacy reduces the risk of migration/relocation by Mexican nationals, but it also, however modestly, enables the continuation of U.S. employers' use of undocumented labor. Undocumented workers are by definition displaceable.

Massey, et al. (1987: 184-185) wrote: "Although temporary migration is numerically dominant, our understanding of migrant networks and the way they operate suggests that recurrent and settled migrations are crucial to supporting temporary migration and making it widespread." In other words, the dynamic of some newcomers permanently settling supports a system where other newcomers are transient, or at least unsettled. The best answer to the settlement/sojourner debate may be "both."

It follows that (a) those who are able to settle accrue a little more social capital and thus (b) that their local political voice is comparatively more prominent than that of sojourners and (c) that their links with natives in the receiving community are more numerous and nuanced. These overlapping dynamics seemed to be operative in my Georgia research site and explain how a program responsive to newcomers could overlook those newcomers who were sojourners (Hamann 1999a). The louder voice of settled newcomers there helped obscure the less organized, less connected voice of sojourners. A local Latino community organization that was started in 1997 with external assistance from some applied sociologists from a Mexican uni- 
versity, soon had a schism, with some Latino community leaders arguing for the inclusion of undocumented community members and others arguing against that inclusion. The exclusionary side prevailed; the voice of undocumented newcomers within the organization and the larger community remained muted.

In 1999, the INS estimated that seventy-five percent of the Latinos in my research site lacked legal documentation (Dyer 1999). While I worried that this estimate was quite high, Hernández-León and Zuñiga (personal communication) who have conducted more thorough survey work in the community found the INS estimate to be plausible. It follows that other U.S. locations that have experienced substantial influxes of Mexican newcomers subsequent to the 1986 amnesty also have high portions of undocumented adults, though, because of the self-perpetuating nature of migration streams, "New Latino Diaspora" sites (Wortham, et al. 2001) are hardly the only sites with substantial numbers of undocumented newcomers.

Hagan (1994:160) has written, "The precarious and clandestine nature of undocumented life, with its constant ambiguity, discourages the migrant from making long-term plans. Thus decision making evolves into a continual process, whereby decisions shift with changing sets of opportunities, attitudes, and social relations in both the home and host community." This vulnerability and related tentative attachment to place pertains both to undocumented students and to documented students who live with undocumented parents/guardians. (Because birth in the United States automatically confers U.S. citizenship to the baby, this latter scenario is common.)

Even though the 1982 U.S. Supreme Court case of Plyler v. Doe protects the right of undocumented minors to attend public school, it is not hard to envision many of the ways lack of legal status could be disruptive to a student's school experience. The at-school legal protections assured by the Plyler v. Doe decision last only through high school. As Dyer (1999) laid out in an Atlanta Journal-Constitution feature story, the promise of college admission and the premise of a college prep curriculum are misguided for an undocumented student. Regardless of that individual's particular talents, he/ she cannot go to college. ${ }^{7}$ With the rewards of a high school diploma as a terminal degree limited (essentially confining those with only a high school diploma to work in the secondary sector), the relative attractiveness for an undocumented student of dropping out sooner and earning money (by illegally obtaining a job) is real. (Remember school attainment is not rewarded in the secondary sector.) 
Mahler's (1998), Hagan's (1994), Pugach's (1998), Valdés' (1996), Guerra's (1998) and Boehm's (2000) separate findings that obtaining legal status increased the binational mobility of members of the newcomer groups they were studying also pertain. (They hypothesized that mobility increased because the cost and risk of crossing the U.S. border is dramatically reduced for those with papers.) Thus legal status issues can contribute to the likelihood of a student being a sojourner student in a number of ways. Being undocumented or depending on undocumented family members makes attachment to place highly tentative. Yet, obtaining legal status facilitates the economic risk- minimizing (Stark 1991), cross-border exploitation of opportunities in two nation states, thereby increasing mobility and making bicultural literacy that much more salient.

At least three dynamics were in play for newcomer Latinos in my research site that put in question the permanence of many: Most Latino wage-earners were in vulnerable positions in the secondary sector of the local economy; many lacked legal work documentation; and many maintained substantial links to their original sending communities (Hamann 1999a). The significance of these dynamics is indirectly illustrated by Latino student mobility data from the more impacted district that I studied (District 1). 


\begin{tabular}{|c|c|c|c|c|}
\hline $\begin{array}{c}\text { By school } \\
\text { system } \\
\text { grade level } \\
\text { divisions }\end{array}$ & $\begin{array}{c}\text { Total } \\
\text { number } \\
\text { of } \\
\text { Hispanic } \\
\text { students }\end{array}$ & $\begin{array}{c}\text { Born in } \\
\text { Mexico or } \\
\text { other Latin } \\
\text { American } \\
\text { country by } \\
\text { number and } \\
\text { percentage }\end{array}$ & $\begin{array}{c}\text { Born in USA } \\
\text { by number } \\
\text { and } \\
\text { percentage** }\end{array}$ & $\begin{array}{c}\text { Born in } \\
\text { Georgia by } \\
\text { number and } \\
\text { percentage** }\end{array}$ \\
\hline (PreK-2) & 520 & $204(39 \%)$ & $316(61 \%)$ & $110(21 \%)$ \\
\hline$(3-4)$ & 174 & $90(52 \%)$ & $84(48 \%)$ & $23(13 \%)$ \\
\hline$(5-6)$ & 255 & $189(74 \%)$ & $66(26 \%)$ & $14(5 \%)$ \\
\hline Junior High & 207 & $162(78 \%)$ & $45(22 \%)$ & $2(1 \%)$ \\
\hline High School & 251 & $192(76 \%)$ & $59(24 \%)$ & $6(2 \%)$ \\
\hline $\begin{array}{c}\text { District } \\
\text { Total }\end{array}$ & $\mathbf{1 4 0 7}$ & $\mathbf{8 3 7 ( 5 9 \% )}$ & $\mathbf{5 7 0 ( 4 1 \% )}$ & $\mathbf{1 5 5 ( 1 1 \% )}$ \\
\hline
\end{tabular}

* This data comes from District 1's successful Title VII -Systemwide Bilingual Education grant

** The data in these columns are overlapping. Those born in Georgia are also counted as born in the U.S.

Figure 1 shows that only eleven percent of the 1,407 Hispanic students enrolled in District 1 during the 1996-97 school year had been born in Georgia. ${ }^{8}$ An unknown but smaller portion of those had been born within the boundaries of the district and had lived and gone to school continuously there. Even at the youngest grade levels (Pre- Kindergarten to Grade Two) and ages ( 4 to 7$)$, scarcely more than a fifth had been born within the state. That overall thirty percent had been born in other U.S. states and fifty-nine percent had been born in Latin America suggests many may have been members of economically dislocated households or households participating in the traditional U.S./Mexico cyclical migration pattern (even though several scholars have identified this as becoming less common in recent years [e.g., González Baker, et al. 1999]). That fifty-nine percent were born outside of the country suggests that a high percentage might not have legal documents and that a higher percentage lived in households with undocumented adults, which would lend their households an extra vulnerability and tentativeness in relation to the host community. In short, Figure 1 shows that attachment to community among the newcomer population had had little time to incubate and that factors that interfere with attachment could be extant. 
The probability that many students in my dissertation site were sojourner students is further supported by data assembled by Hernández-León and Zuñiga (2000), two sociologists who studied the same community. In a survey of more than 100 Latino parents, they found that twenty-two percent of fathers and twenty-four percent of mothers did not expect to still be in the studied community three years hence. These parents expected to be mobile. It follows that many or most of their children were likely to be sojourner students. Because even parents who hoped to stay could not assure their geographic stability (because of the vulnerability of the jobs they occupied and/ or their vulnerable legal status) and because other parents might choose to send their children back to the parents' birth country (to be raised by grandparents or relatives in a morally purer environment)—as had Mexican immigrants described by Trueba (1999) and Guatemalan immigrants described by Hagan (1994) — it follows that even a larger portion of Latino newcomer students than the twenty-plus percent hinted at in Hernández-León and $\mathrm{Zu}$ ñiga parent interview data might be sojourner students. A local pre-Kindergarten to grade two elementary school that had had a majority Latino enrollment since the early 1990s averaged having only two thirds of the students who started there in Kindergarten finish second grade. ${ }^{9}$ In essence, in the span of three school years, roughly a third of the original student body was gone, replaced by disconcerted newcomers who may have already accumulated a little school experience elsewhere.

These percentages still leave intact the argument of those on the settler side of the settler vs. sojourner debate-perhaps the majority of newcomers were settling — but also reminds us of Benmoyer's and Skotnes' caution (1994:15) to be humble about the adequacy of generalizations regarding transnational migration. "Few actual individual lives fully conform to the master narratives." The idea of sojourner students is a correction to the master settler narrative and it follows that within the sojourner student category there is heterogeneity.

\section{Inauthentic Citizenship}

Because we as a species interact with the world by way of a learned code of signs and symbols (Geertz 2000), it follows that the political, social, and economic processes previously described are simultaneously generated by and understood through the mediation of culture. Members of the host community and newcomers in migration receiving sites construct and contest understandings of each other and their respective places in the community and larger society. From this negotiation, there are ideas extant in the public 
sphere and internalized by host and newcomer that mark some types of people as less belonging. Members of sojourner households are often so marked and, in their risk minimization strategies of maintaining attachments elsewhere, they ironically contribute to this construction. ${ }^{10}$ Thinking of citizenship not strictly in legalistic terms but rather as the right to full participation in the public sphere and full membership in the community (Joseph 1999), one could say that some members of a society reject the authenticity of others' bids for citizenship.

Building on this idea, one could posit the "inauthenticity" of the American citizenship of many Latino newcomers in the United States and the related support this would give for the emergence of "nomadic" (Joseph 1999) or sojourner identities. There are inhibiting factors at the receiving community end that limit newcomers' opportunities and willingness to relocate permanently and their willingness to imagine themselves as permanently relocated (Anderson 1991). Goldring has explained, "The experience of migrating to a country where hegemonic racial constructions locate them in a disadvantaged position certainly contributes to people retaining ties and identities associated with their home countries and communities as these offer a refuge from U.S. racialization" (1998: 170). The status displays of returned migrants (e.g., the displays of acquired material wealth like cars and fancy clothes) noted by Hagan (1994) and Guerra (1998), likely were manifestations of the dynamic Goldring described. In Tehuixtla, Mexico, temporarily returning migrants were at or near the top of the local social and economic pyramid, rather than occupying lower tier statuses akin to those available to them in the U.S. (Ainslie 1999).

For many Latino newcomers, recognition by the host society is incomplete, as often is their own certainty of allegiance to their adopted country. As Gutiérrez has written,

$[U]$ nder the circumstances that have evolved over the past 30 or 40 years, it may make more sense to ask why ethnic Mexican and Latino migrants and immigrants would choose to become "assimilated Americans" rather than continuing (as many have for years) to operate in the social and cultural interstices of the nation-states through which they travel, live, and work. As the contradictory forces unleashed by economic globalization continue to tug and pull against the traditional structures that have in the past given citizenship and national affiliation meaning, it may well be that the most logical decision for transmigrants and even permanent immigrants is one that actively ... disavows allegiance to a single national entity [1999:327]. 
While those referred to by Gutiérrez (1999) above may actively manipulate opportunities in two nation states (rather than one) and thereby gain advantage and/or reduce their economic vulnerability (Stark 1991), such transnational manipulation can also have a cost. According to Mahler (1998), the practices, processes, and positionalities that intertwine to create transnationalism from below are sometimes counterhegemonic, but sometimes they reiterate the stratified status quo.

Joseph notes that "citizenship is not organic but must be acquired through public and psychic participation" (1999:3) and that "Notions of citizenship are infused with public images, official definitions, informal customary practice, nostalgic longings, accrued historical memory and material culture, comforting mythologies of reinvention, and lessons learned from past rejections" (1999:5). Of course, public participation in the activities of citizenship reiterates the seeming naturalness of those activities as citizenship criteria, even if the enactor's bid for recognition is deemed inauthentic.

Borrowing terminology from Luykx (1999), schools are "citizen factories." Because sojourner students are less accommodated at school than other populations (a point clarified in the next section), it follows that their bids for full citizenship can be undermined by the way they and citizenship are constructed there. Returning to Smith and Guarnizo's (1998:9) emphasis that studies of transnationalism need to consider the continued salience of agents of the receiving state (i.e., schools), we return to the inherent tension between transnationalism and the state, between the sojourner students and the school. Formal political power is accrued through the structures of the state, those accruing such power have interests in maintaining the preeminence of state structures and instruments (e.g., schools and curricula) as the vehicles for accruing that power (Labaree 1997). ${ }^{11}$ Relatedly, they also have an interest in limiting the access of others to that power, though not necessarily in a blatant manner. Questioning the authenticity of a portion of the population's claim to citizenship is one means of reducing that population's access to power. This is not always an issue of challenging legal citizenship, nor is it always overt. Those who self-question their sense of citizenship or who sense it being questioned will often develop nomadic identities (Joseph 1999).

Some sojourner students were born in the country where they presently live (and thus, at least in the United States have claim to legal citizenship); some were not. All live in economically vulnerable, transnational households. All need and will continue to need to negotiate multiple cultural domains, not just because of the differences between their households environments and the host society's schools, nor just because their geographic impermanence suggests they will sometime live in another place where the most use- 
ful literacies (Guerra 1998) will be different, but also because any bid for host-society inclusion will most likely be at best only partially successful.

\section{The Challenge to School Governance and Curriculum}

Hopefully several points are clear from the previous sections. The dynamics driving transnational migration (e.g., transnationalism from below) combined with site, region, and nation-specific political and cultural ecologies (e.g., laws defining citizenship, ethnic-typing of jobs) make some transnational/newcomer students sojourner students. This section seeks to clarify how sojourner students' needs and scholastic experiences differ in substantial ways from their more geographically anchored classmates, making an assimilationist curriculum not just imperious, but incomplete. This adds a novel wrinkle to the usual debates about what immigrant students should learn. Sojourner students need to develop literacies apart from those needed to negotiate a community in north Georgia, or even a country like the U.S. (Guerra 1998).

If these are some of the educational issues that pertain to sojourner students, there are still at least two unaddressed dilemmas that suggest making schooling more responsive to sojourner students will not be easy. Why should community schools teach students to be successful somewhere else? Is this as important as teaching the students who will stay in the community as adults? Both of these dilemmas are tied to the history of public education in the United States and the continuing structure for how it is funded and governed. Spindler, in an introduction to an essay by Peshkin about community/school linkages in "Mansfield," speaks both to the dilemmas noted above and to the value of an anthropological lens to consider those dilemmas. He wrote,

In the anthropological view, schooling is cultural transmission. Schooling exists, in this view, to recruit new members into the community (usually its own offspring) and maintain the cultural system. Mansfield schools exist to maintain Mansfield, in the narrow sense, and to maintain a culture and world view appropriate to the small, stable community in the broader sense. [1982:16].

Tending to the opportunities and needs presented by sojourner students is not easily consistent with the community defining and community sustaining roles performed by public schools. Perhaps sojourners just represent a 
more acute case than the long tradition of immigrant students who have not been served well in U.S. schools, despite potent myths to the contrary. (See Olneck [1995], Smith and Guarnizo [1998: 16], and Valdés [1996:23-24].)

The experience of an Atlanta-area high school ESOL (English to Speakers of Other Languages) teacher illustrates another dilemma, the case of newcomers with discontinuous school experience. At a conference presentation, that teacher (Lopez-Butner 1997) autobiographically described the challenges and pragmatic curriculum revisions she made as she struggled to teach adolescent, Latino, ESOL students who had limited previous school experience and who were unlikely to stay in school long enough to accrue the needed course credits to pass Georgia's high school graduation requirements. ${ }^{12}$ With the formal rationale for her instruction impractical (i.e., steering students toward graduation), she felt compelled to improvise a kind of economic survival curriculum which she hoped would help such students as they transitioned into the workforce. Feeling like she was racing against time with each student - the school discontinuation rate among these students was quite high-her guiding curricular rationales were to prioritize what students most needed to know (e.g., workplace rights, survival English) and to hope students would be sufficiently engaged with her material that they would remain in school a little longer.

Having had no contact with Ms. Lopez-Butner since 1997, I have no idea whether she is still teaching such a mobile, vulnerable student population nor whether she still thinks her "survival skills" curriculum is the most useful way she can respond to these students' circumstances. I have, however, continued to consider her response to the inadequacies of the regular state curriculum and the ordinary organization of school. I agree with her implicit diagnosis that sojourner students like the ones she taught needed something different than the official curriculum.

\section{A Theory of Curriculum}

Curriculum is a third partner at the instructor/student interface. Curriculum-i.e., the content taught in classrooms and its recommended modes for delivery-is also one of the most contested topic areas in American schooling. Particularly controversial are curriculum decisions related to the schooling of language minority students (Wong-Fillmore and Meyer 1992), a label that most sojourner students fit within. Two main points relevant to sojourner students should emerge from the discussion which follows: (a) non-inclusive curriculum can and does disadvantage sojourner stu- 
dents, and (b) creating curricula that are responsive to sojourner students requires a dramatic rethinking of school organization, curriculum, pedagogy, student needs, and the relationships at the instructor, student, curriculum nexus. Writing of changes needed to accommodate immigrant students at the secondary level, Ruiz-de-Velasco and Fix (2000) recommend that attention needs to be paid to:

- limited staff capacity (e.g., few trained to work with non-native English-speakers),

- organizational rigidity (e.g., the dependence on 50 minute class periods),

- lack of accountability and standards, ${ }^{13}$

- knowledge gaps regarding how to build on immigrant students existing capabilities and how to appropriately assess their learning.

According to Freire (1970), students most readily learn ideas, facts, and perspectives that help them describe and negotiate their world-i.e., their circumstances and their aspirations. Freire's assertion seems to be supported by a range of research. For example, a team of cognitive psychologists, Kuhn, et al. (cited in Clemens [1999]), have found that what people already know influences how they will acquire new knowledge. Heath (1983), Au and Jordan (1981), and a long list of others, have found that non-mainstream students's school engagement and performance improved when the curriculum was adjusted in culturally familiar ways and included material about their communities and cultures. By these interpretations, to the extent sojourner students in the United States encounter a curriculum that captures neither their realities nor goals, they are disadvantaged.

Connell's (1993) concern with curricular justice overlaps with Freire's (1970) diagnosis. A curriculum that ignores or discounts some students' personal and cultural histories while celebrating others' is unjust. The injustice comes from the curriculum's varied accessibility, its varied relevance, and/or its failure to acknowledge. Connell also noted that assessment is an ubiquitous partner of curriculum and one that can be equally implicated in the creation of disadvantage. Culturally-bound assessment instruments (e.g., standardized tests given in English) that do not acknowledge a student's cultural background and related knowledge and learning styles will mismeasure what a student knows, will mislabel that student's skills and capabilities, and will construct a student's school struggles as an individual problem or limit of the student rather than as a multilateral failure.

Another issue about curriculum and disadvantage that deserves noting is the way various components relate to each other. This pertains both to the 
linkages (or absence thereof) between the materials students consider in one classroom and one subject versus those considered in another classroom and subject and also to the linkages between the curricula that students are presently encountering versus what they have previously studied. Sizer (1984) and Powell et al. (1985) have described how the schizophrenic mix of multiple subjects and teachers that students encounter on any given day at school is a source of disadvantage in that students are not assisted in integrating and synthesizing knowledge nor in applying lessons from one context to another. (See also Ruiz-de-Velasco and Fix [2000].) While Sizer's and Powell's criticisms were focused at the secondary level and were intended to document collective disadvantage (versus one that disproportionately affects one group of students more than another), their thesis about the consequences of studying multiple topics in disjointed fashion describes a type of disadvantage that is felt acutely by sojourner students.

Even more than the secondary students described by Sizer (1984) and Powell, et al. (1985), primary and secondary-level sojourner students have to negotiate the schizophrenic mix of school experiences collected in different places, different systems, and different countries. Nor are disjointed school experiences their only source of knowledge in need of synthesis and internal reconciliation. Sojourner students, like other students, need to square their away-from-school learning with their at-school learning. With both the range and the bulk of the content of this external learning usually unknown and unaccounted for by sojourner students' teachers, those teachers' assistance of sojourner students' attempts at synthesis is hampered, profoundly hampered if there are no conscious attempts to resolve the problem.

The school organization encountered by sojourner students usually does not account for sojourner students' need for assisted synthesis opportunities and the meta-cognitive awareness that such opportunities could bring. Because of the disjointed nature of sojourner students' schooling, it is particularly important that sojourner students gain learning-how-to-learn skills, but instead they often encounter extra discontinuity-i.e., pull-outs-where the focus is narrowly linguistic rather than meta-cognitive. (Pull-outs involve pulling a student out of his/her regular classroom for individual or small group instruction.)

According to Thomas and Collier (1997), the pull-out intervention strategy (used in my research site and common elsewhere) to help English Language Learning (ELL) students learn English and to be ready for mainstreaming, does not seem to close the achievement gap between initially ELL students and first language English speakers, even as the ELL students' Eng- 
lish abilities improve over time. Moreover, the language-centric diagnosis of the educational challenge seems incomplete (as evidenced by students' failure to catch up in other subjects).

A further reason for ELL students not closing the achievement gap may be that the pull-outs mean that pulled-out students have to negotiate an even more disrupted curriculum. Pulled-out students would have the additional task of figuring out how to connect the lesson from the pull-out session with the rest of the mix of lessons they are exposed to. Given the organization and hectic pace of most instructors' school days, there is often little opportunity to ensure that a pull-out is sufficiently coordinated with the regular curriculum the student is studying. (This was clearly the case in my Georgia research site [Hamann 1999a].) What students miss in their regular classroom while being pulled out can be an additional area for problems. Thus, for sojourner students, disjointed lives and disjointed school experiences are too often met with disjointed and misdirected so-called remedial strategies.

\section{The False Promise ofAssimilationist Curricula}

The importance of the social imagining of newcomers by members of the host society for the production of classroom and community ontologies is well documented. Using data he collected in Britain, Gillborn (1997) recorded how teachers' attitudes and expectations for students varied by race/ ethnicity, in that case by having higher expectations for Asian minority students than West Indian. He also corroborated that where expectations lead outcomes seem to follow. Ogbu (1987) and Spindler and Spindler (1998) make reference to a similar dynamic frequently being in play in the United States. High expectations generally produce high achievement, while expectations of low achievement often become self-fulfilling prophecies. Of course, expectations regarding achievement are not the only ones projected on newcomer students, so too are expectations about permanence, background, need, and the prospect of incorporation.

To understand the cultural politics stimulated by local democratic approaches to resolving dilemmas of cultural diversity, one must look more closely at the nature of the political struggles being fought through the politics of needs interpretation. What are subordinate groups attempting to achieve in their struggles to reconfigure the way their "needs" are defined and their political claims legitimated? How are their claims subverted and potential power defused by dominant 
and authoritative definitions of the "need" of minority students? . . . And what does this say about the potential . . . to achieve social justice and greater equality, particularly in the public sphere that surrounds education? [Hall 1999: 138].

Recognizing, let alone tending to, the needs and capabilities of sojourner students is not easy because, in part, the politics of local needs interpretation obscures their presence and a mobile/readily displaced population has little chance to organize to participate in community politics. In my Georgia research site, a they-are-here-permanently discourse and the "pro-immigration script" (Suárez-Orozco 1998) worked in tandem to rationalize a certain response to newcomers. To quote the local newspaper, "The Hispanic community is a hard-working force shoring up industry by filling some of the toughest manual labor jobs around. They provide an element of cultural variety as well as an example of intensive familial ties." The same editorial later continued: "This virtually ignored minority needs to be part of our city and county just as much as any other group if we all expect a future here together."

In my Georgia research site, the host community's willingness to act was clear, but so was the diagnosis of the challenge and the identified locus for change. They needed to be allowed (compelled?) to become like us. That viewpoint, however, was flawed not only at the level of cultural imperiousness, but also at the logistical level. It was not clear that all of the they would be present long enough to learn sufficiently how to be like the native population. Nor was the prospect of newcomers' skepticism about the like us opportunity accounted for. (See Ogbu [1987].) The concern of Gene Garcia, former U.S. Undersecretary of Education, quoted below, was not addressed:

There is some evidence that assimilation may actually inhibit academic success. Studies of Mexican immigrants suggest that those who maintain a strong identification with their native language and culture are more likely to succeed in schools than those who readily adapt to U.S. ways. [1998:viii]

An allegedly assimilation-oriented curricular argument that says something like "they are in our country they need to learn our history" but which fails to connect newcomer students' situations to the cultural and historical orientations that are being taught and that fails to gain students' assent creates students' disadvantage. According to Wong Fillmore and Meyer, "The dropout rate for Hispanic students reflects the difficulty of making progress 
in a school system that has not been especially friendly to them" (1992:627). Trueba's finding, echoed by many others, also pertains, "If children manage to retain a strong cultural self-identity and maintain a sense of belonging to their sociocultural community, they seem to achieve well in school" (1999:260).

Wong Fillmore and Meyer (1992) devote much of their article to discussing the philosophical conflicts that hobble many efforts to educate language minority students effectively. Noting Ralph Tyler's old point that without appropriate goals the process of curriculum development is directionless, Wong Fillmore and Meyer found that there is an often unarticulated conflict between two competing goals for language minority students-the goal of cultural assimilation versus the goal of cultural pluralism. Describing this conflict, Rachel Moran (cited by Wong Fillmore and Meyer [1992:633]) wrote,

If assimilation is the relevant goal, LEP and NEP students succeed to the extent that they become largely indistinguishable from their English-speaking classmates. By contrast, if cultural pluralism is the objective, LEP and NEP children who emerge from the educational process identical to their English-speaking peers are failures. ${ }^{14}$

Circumstantially, sojourner students find themselves at the middle of this conflict, yet for them matching an Anglo-conformist cultural model (i.e., the model promoted at school) would be poorly adapted to many of the circumstances they need to negotiate (both geographic circumstances and intra-familial ones).

Those on the assimilationist side may argue that not asking language minority students (and sojourner students) to master the same rigorous content as other students is discriminatory. But appealing as this argument may first appear, it has some important flaws. First, it promotes the ideas that there is a common culture that should be studied and mastered at school and that only the learning of that common culture matters (as a school task). Who gets to define that common culture is unclear, but those with less voice and political power have less input. Second, the argument ignores that sojourner students (as well as other students) need multiple cultural literacies because they are not just negotiating one culture (Guerra 1998). Gaining adeptness with the host community's culture is a need, but only one of many needs. ${ }^{15}$ Finally, an assimilationist orientation also overlooks issues of students and educators together determining what is important to learn. What students need to know requires attention to context. That question becomes irrele- 
vant, however, if a student does not assent to learn. Making schools responsive to sojourner students requires winning such students' engagement.

\section{Responding to Sojourner Students}

In an attempt to reconcile the differences between the communication process explanation of minority student school failure-a.k.a. the "cultural mismatch" hypothesis (e.g., Hymes 1962, 1972, Gumperz 1982a, 1982b, Heath 1983) —and the more structurally-oriented, racialized-labor-market explanation—a.k.a. the "involuntary minority" hypothesis (Ogbu 1987)_ Erickson (1987) relied on Vygotsky (1978) to make a central argument about curriculum. Erickson claimed that all students learn at school, but not all students learn what the school ostensibly wants them to learn (i.e., the formal curriculum). Noting that learning in Vygotsky's "zone of proximal development" (ZPD) requires assent on the part of the student and that school teaching should be responsive to students' ZPDs, Erickson further noted that several factors can interfere with student assent. Assent is less likely if the instructors' ways seem unfamiliar, illogical, or hostile to the student's identity and/or background. Based on peers' or parents' negative experiences with schools and/or the mainstream culture and political economy, some students come to school already skeptical.

These challenges are not insurmountable. According to Erickson's assent framework, a first challenge in building a curriculum for sojourner students is to calculate how to earn such students' assent. One answer, consistent with Freire (1970) and Connell (1993), is to have a curriculum and assessment system that recognizes the realities in which such students live, the topics in which they are interested, and the culturally-related ways in which students are best at indicating/applying what they know. Faced already with the challenges of gaining one's bearings in a new place and feeling uncertain about the duration of one's stay, sojourner students may need even more affirmation of their existing knowledge and its potential application to present circumstances than do most students. Summarizing one portion of this challenge, Guerra wrote.

But if what I have discovered in the course of my research is truethat Mexicanos are generally well equipped to construct complex pieces of writing - then we must also look for ways to create classroom environments in which students feel safe enough to share the 
funds of knowledge that they bring into the classroom so that we then have something on which to build. [1998:163]

A second curricular challenge in the education of sojourner students is to figure out not just a curriculum that builds on what such students already know, but one that is also conscious of the circumstances sojourner students negotiate and likely will need to negotiate in the future. Using W.E.B. DuBois' famous term, Smith and Guarnizo (1998:17) mention the "doubleconsciousness" required by transmigrants to negotiate the various domains they inhabit/traverse. Writing from a very different perspective, Parker, et al. (1999) have recently asked whether the time has come for multinational curriculum development. Perhaps such an effort would particularly benefit sojourner students. Though hardly the only point to focus on, a useful skill that could be consciously promoted by such a curriculum would be the capacity to "culture switch" (Clemens 1999: 116).

The Funds of Knowledge teacher training initiative at the University of Arizona suggests another promising response to the needs of sojourner students. In that program, both in-service and pre-service teachers visit Latino households to learn more about the backgrounds of such students and to inventory and appreciate the funds of knowledge that such students have accumulated. (See Moll et al. [1992], Gonzalez et al. [1995], and Moll and Gonzalez [1997].) Enabled by improved awareness of student backgrounds, teachers are then positioned to customize instruction, to provide active scaffolding for student learning, as per Vygotsky's (1978) "zone of proximal development." Being enabled, of course, is different from actually engaging in a practice. There still need to be structures and habits of action that allow teachers to use their new awareness of students' funds of knowledge. Fully scripted, externally developed, classroom curricula, which are becoming more popular, are an example of an obstacle that would impede teachers' application of their new awareness. Rarely do such curricula include the full range of content knowledge pertinent to a sojourner student, but more importantly they restrict an instructor's flexibility to adapt pedagogy and curricula to win a student's engagement. The scripted models, if research based, are typically based on what works for so-called mainstream students, not what works for sojourners.

Equality of educational opportunity should not be confused with homogeneity of educational opportunity. The challenge of equal education is to ensure all students are engaged by equally rigorous, responsive, and thoughtful curricula, but not by a single curriculum. The curricula for sojourner stu- 
dents should overlap with the curricula other students encounter, perhaps substantially, but not completely. The sojourner student curriculum likely will overlap more with the curriculum for some types of students than for others; for example, there is a lot of overlap in background, circumstance, need and aspiration between sojourner students and permanent newcomer students. The curriculum for both groups should reflect this shared common ground. However, attempting to accommodate permanent newcomers but not sojourner students leaves intact the ideas that some students merit more accommodation than others and that stratifying treatments and stratifying outcomes are $\mathrm{OK}$.

Mahler (1998:84) notes that scholars of transnationalism are frequently asked whether or not the children of transnationals are likely themselves to be transnational. She then clarifies that such questions are not easy to answer because they require longitudinal study. Historical analyses might permit a partial answer, but even they would only document what had been. From an historical perspective, the trend-line seems to be that, as the world economy continues to change, the movement of people within and across borders seems also to grow. Responding a different way to the question posed by Mahler, it seems unwise and unfair for schools to presume that sojourner students will not (a) be mobile as adults or (b) not be needing the intellectual tools to negotiate communities perhaps very different from the one where they are being schooled. The dilemma of asking schools, in effect, to serve the interests of other communities is real, but failing to account for the mismatch between transnationalism from below and assimilative schooling leaves sojourner students in jeopardy.

\section{Acknowledgements}

This chapter is derived from a paper originally presented at an invited session of the 1999 American Anthropology Association Annual Meeting in Chicago, IL. The title of the session was "Latinos Abarcando Dos Mundos" [Latinos Embracing Two Worlds]. 


\section{Notes}

1. For this, I operate from the social improvement view of schooling shared by most educators, administrators, and politicians, [and] by large sectors of the public (Spindler 1982:16) - i.e., I see schools as potential instruments of change and improvement, as loci where the circumstances and needs of sojourner students could be better addressed.

2. Some may ask what, in a U.S. context, distinguishes a sojourner student from the already existing category of migrant student. To be sure, they are overlapping categories. Like migrant students, sojourner students are mobile and economically vulnerable. Both often have limited proficiency in English and incomplete literacy in standard Spanish. Latinos predominate in both groups. But migrant student is also legal designation, referring to students who are eligible for federally funded Title I Migrant Education support services. By virtue of their parents' involvement with agriculture or food processing, many sojourner students temporarily qualify for Migrant Education support, but others do not. Traditionally, migrant students' families have been involved in field agriculture labor and moved from harvest site to harvest site. Family movement was frequent and reasonably predictable. Migrant children's schooling was discontinuous and difficult, but, however inadequately, at least their mobility was formally accommodated for (albeit usually with meager extra resources, rather than a reconceptualization of curriculum content and delivery for such students). There are a number of useful studies and curricula pertinent to helping such students-e.g., Prewitt-Diaz, et al. (1990), LeBlanc Flores (1996). Such efforts and the federally supported Migrant Education infrastructure are both examples of some accommodation to migrant students. In comparison to migrant students, I want to characterize sojourner students as neither so consistently mobile, nor so overtly responded to. Sojourner students are mobile, but not mobile according to a consistent pattern like following harvests. Rather their movement always seems possible, but is rarely anticipated. The if and when of displacement are uncertain.

3. I have written elsewhere (author 1999b) that both before and during the implementation of the binational partnership there were two main ways that host community members in my Georgia research site understood the Latino newcomers and, in turn, sought to accommodate them (or not). These two types of responses matched Suárez-Orozco's (1998) theoretical models of a pro-immigration script and an anti-immigration script. The anti- 
immigration script is rather straightforwardly xenophobic and is embodied in both crass anti-newcomer demonstrations like the one David Duke organized in Siler City, North Carolina (Yeoman 2000), as well as formal policy initiatives like California's Proposition 187. In deceptive contrast, the pro-immigration script casts newcomers as hardworking, self-sacrificing, resourceful, familial, religious and virtuous in still other ways. Their willingness to take jobs that no one else will is both celebrated and touted as a counterargument to those who claim the newcomers are displacing natives. The script embeds ideas that America in general and the reference community in particular are attractive to hardworking immigrants who, like immigrant generations before them, seek to pull themselves up by their own bootstraps. The pro-immigration script thus can find broad public appeal because of its base in American nostalgia. In essence, the script suggests that the local community provides fair opportunity and that is desirable. It reiterates a sense that the local economy and local social institutions should continue to operate unchanged.

4. I suspect that a complementary definition of the sojourner student that referenced adults in adult education programs could be posited. However, adult education is not marked with the homogeneity of implementation that $\mathrm{K}-12$ education is, nor is adult education so commonly marked by the assimilative emphasis characteristic of $\mathrm{K}-12$, so I limit my definition to students in the $\mathrm{K}-12$ system.

5. There are some obvious oversimplifications embedded in dual system theory. For example, in the Spener quote (1988:138) two paragraphs above, immigrants are identified as a buffer to those in the mainstream of the secondary sector which itself is a buffer to the primary sector. But noting newcomers' extra displaceability as buffers of buffers if anything strengthens the point that many laborers and their families are circumstantially positioned as sojourners.

6. To explain ethnic job-typing a bit more fully, the emergence of a racial/ethnic association with a particular job category creates both an opportunity and a trap for newcomer workers. Because, for example, a certain job is seen as Mexican work, the supply of potential workers is reduced. This increases the likelihood of a Mexican newcomer finding work in that niche. This prospect, in turn, supports formal and informal transnational labor recruitment networks. However, this same dynamic marks some work as, for example, non-Mexican, limiting prospects for advancement and abetting job turnover. 
7. In response both to Dyer's (1999) article and more generally to the dilemma of the legally constrained educational future of undocumented high school graduates, the Georgia State Board of Regents in 1999 recommended that the Hope Scholarship program be extended to all Georgia high school graduates with a qualifying GPA without regard to such students' legal status. If enacted, this policy would allow undocumented students to pursue higher education in Georgia, though it would leave unresolved the illegality of employing them.

8. I collected the detailed enrollment data that the more impacted of the two studied districts had assembled. The second district at that time had not collected similar data (and thus I did not collect it).

9. The highest portion of continuing students since 1995 was the seventy-one percent recorded in for 1998-99. The school district did not further subdivide this tally to calculate continuation/discontinuation by race/ ethnicity, but there was no reason to suspect that white or African-American students (the other two big groups at the school) were more likely to leave than Latinos and there were several reasons to suspect that Latino students were more likely to head elsewhere before finishing.

10. My point here is not to construct the fault for the limited opportunities typically encountered/developed by transmigrants on the backs of those same transmigrants. Rather I want both to note that the risk-minimization strategy embedded in transnationalism from below can impede opportunity maximization and to clarify that this is so because of the mismatch between the strategies rewarded by, in this case, the U.S. educational structure and the strategies required by a transnationalism from below.

11. Labaree (1997) explains that U.S. schools serve three contradictory purposes, one of which is to stratify the population according to credentials earned and thus to rationalize the unequal distribution of wealth and influence. That is the dimension of schooling's social consequences that is referenced here.

12. Using examples from Texas, Illinois, and Virginia, Mace-Matluck et al. (1998) address the issue of immigrant adolescents with limited school experience in their book entitled Through the Golden Door: Educational Approaches for Immigrant Adolescents with Limited Schooling.

13. Because many assessment instruments are inappropriate for English language learners (ELLs) (which many sojourner students are), schools can 
exempt their ELLs from taking such tests. While this is superficially fair and avoids the stigma of a low score on an inappropriate test, it means that, in this era of high-stakes testing and educator accountability (accountability for students' achievement as narrowly measured on timed, standardized assessments), schools can sidestep being accountable for the performance of their ELLs and can prioritize teaching those students for whom they will be accountable.

14. LEP is the common shorthand for limited-English-proficient and NEP means non-English-proficient. Federal law requires schools to make explicit accommodations to assure that identified LEP and NEP students have equal access to the curriculum.

15. Sojourner students in particular would benefit from the "additive biculturalism" orientation promoted by Gibson (1997). 


\section{References Cited}

Ainslie, Ricardo C.

1999 Cultural Mourning, Immigration, and Engagement: Vignettes from the Mexican Experience. In Crossings: Mexican Immigration in Interdisciplinary Perspective. Marcelo M. Suárez-Orozco, ed. Pp. 283-300. Cambridge, MA: Harvard University, David Rockefeller Center for Latin American Studies.

Anderson, Benedict

1991 Imagined Communities: Reflections on the Origin and Spread of Nationalism (Revised Edition). London: Verso.

Appadurai, Arjun

1996 Modernity at Large: Cultural Dimensions of Globalization. Minneapolis: University of Minnesota Press.

$\mathrm{Au}$, Kathryn H., and Cathie Jordan

1981 Teaching Reading to Hawaiian Children: Finding a Culturally Appropriate Solution. In Culture in the Bilingual Classroom: Studies in Classroom Ethnography. Henry Trueba, Grace Pung Guthrie, and Kathryn H. Au, eds. Pp. 139-152. Rowley, MA: Newbury House.

Barth, Fredrik

1969 Introduction In Ethnic Groups and Boundaries: The Social Organization of Cultural Difference. Fredrik Barth, ed. Pp. 9-38. Boston: Little, Brown and Company.

Benmayor, Rina, and Andor Skotnes

1994 Migration and Identity. Oxford: Oxford University Press.

Boehm, Deborah

2000 "From Both Sides" (Trans)nationality, Citizenship, and Belonging Among Mexican Immigrants to the United States. In Rethinking Refuge and Displacement, Selected Papers on Refugees and Immigrants, 8. Elzbieta Gozdziak and Dianna Shandy, eds. Pp. 111141. Arlington, VA: American Anthropological Association.

Brettell, Caroline B.

2000 Theorizing Migration in Anthropology: The Social Construction of Networks, Identities, Communities, and Globalscapes. In Migration Theory: Talking Across the Disciplines. Caroline B. Brettell and James F. Hollifield, eds. Pp. 97-135. New York: Routledge.

Brettell, Caroline B., and James F. Hollifield

2000 Migration Theory: Talking Across Disciplines. New York: Routledge. 
Burawoy, Michael

1983 Factory Regimes Under Advanced Capitalism. American Sociological Review. 48:587-605.

Chavez, Leo R.

1988 Sojourners and Settlers: The Case of Mexicans in the United States. Human Organization. 47:95-108.

1994 The Power of the Imagined Community: The Settlement of Undocumented Mexicans and Central Americans in the United States. American Anthropologist. 96(1):52-73.

Clemens, Elisabeth S.

1999 From Society to School and Back Again: Questions About Learning in and for a World of Complex Organizations. In Issues in Education Research: Problems and Possibilities. Ellen Condliffe Lagemann and Lee S. Shulman, eds. Pp. 105-120. San Francisco: Jossey-Bass Publishers.

Cohen, Yehudi A.

2000 [1971] The Shaping of Men's Minds: Adaptations to Imperatives of Culture. In Schooling the Symbolic Animal: Social and Cultural Dimensions of Education. Bradley A.U. Levinson, et al. eds. Pp. 83-107. Lanham, MD: Rowman and Littlefield.

Connell, R. W.

1993 Schools and Social Justice. Philadelphia: Temple University Press.

Cornelius, Wayne A.

1989 Mexican Migration to the United States: Introduction. In Mexican Migration to the United States: Origins, Consequences, and Policy Options. Wayne A. Cornelius and Jorge A. Bustamante, eds. Pp. 1-21. San Diego: Center for U.S. Mexican Studies, University of California.

Dyer, Jim

1999 The Dreams of Rigo Nunez. Atlanta Journal-Constitution, Jan. 24: C1, C4.

Erickson, Frederick

1987 Transformation and School Success: The Politics and Culture of Educational Achievement. Anthropology \& Education Quarterly. 18(4):335-356.

Forman, Shepard

1994 Introduction. In Diagnosing America: Anthropology and Public Engagement. Shepard Forman, ed. Pp. 1-21. Ann Arbor: University of Michigan Press. 
Freire, Paulo

1970 Pedagogy of the Oppressed. New York: Seabury.

Garcia, Eugene E.

1998 Foreword. In On the Border of Opportunity: Education, Community, and Language at the U.S.-Mexico Line. Marleen C. Pugach. Pp. vii-viii. Mahwah, NJ: Lawrence Erlbaum Associates.

Garcia, Ofelia

1999 Educating Latino High School Students With Little Formal Schooling. In So Much To Say: Adolescents, Bilingualism, and ESL in the Secondary School. Christian J. Faltis and Paula Wolfe, eds. Pp. 6182. New York: Teachers College Press.

Geertz, Clifford

2000 [1965] The Impact of the Concept of Culture on the Concept of Man. In Schooling the Symbolic Animal: Social and Cultural Dimensions of Education. Bradley A.U. Levinson, et al. eds. Pp. 2530. Lanham, MD: Rowman and Littlefield.

Gibson, Margaret

1997 Complicating the Immigrant/Involuntary Minority Typology. Anthropology \& Education Quarterly. 28(3):431-454.

Gillborn, David

1997 Ethnicity and Educational Performance in the United Kingdom: Racism, Ethnicity, and Variability in Achievement. Anthropology \& Education Quarterly 28(3):375-393.

Goldring, Luin

1996 Blurring Borders: Constructing Transnational Community in the Process of Mexico- United States Migration. Research in Community Sociology 6:69-104.

1998 The Power of Status in Transnational Social Fields. In Transnationalism From Below. Michael Peter Smith and Luis Eduardo Guamizo, eds. Pp. 165-195. New Brunswick, NJ: Transaction Publishers.

Gonzalez, Nancy L. Solien de

1961 Family Organization in Five Types of Migratory Wage Labor. American Anthropologist 63: 1264-1280.

Gonzalez, Norma, Luis C. Moll, Martha Floyd Tenery, Anna Rivera, Patricia Rendon, Raquel Gonzales, and Cathy Amanti

1995 Funds of Knowledge for Teaching in Latino Households. Urban Education 29(4):443-470. 
González Baker, Susan, Frank D. Bean, Augustin Escobar Latapi, and Sidney Weintraub

1999 U.S. Immigration Policies and Trends: The Growing Importance of Migration from Mexico. In Crossings: Mexican Immigration in Interdisciplinary Perspectives. Marcelo M. Suárez-Orozco, ed. Pp. 81-105. Cambridge: Harvard University, David Rockefeller Center for Latin American Studies.

Goode, Judith G., Jo Anne Schneider, and Suzanne Blanc

1992 Transcending Boundaries and Closing Ranks: How Schools Shape Interrelations. In Structuring Diversity: Ethnographic Perspectives on the New Immigration. Louise Lamphere, ed. Pp. 173-213. Chicago: University of Chicago Press.

Guerra, Juan C.

1998 Close to Home: Oral and Literate Practices in a Transnational Mexicano Community. New York: Teachers College Press.

Gumperz, John

1982a Discourse Strategies. Cambridge: Cambridge University Press.

1982b Language and Social Identity. Cambridge: Cambridge University Press.

Gutiérrez, David G.

1999 Ethnic Mexicans and the Transformation of "American" Social Space: Reflections on Recent History. In Crossings: Mexican Immigration in Interdisciplinary Perspective. Marcelo M. Suárez-Orozco, ed. Pp. 309-335. Cambridge, MA: Harvard University, David Rockefeller Center for Latin American Studies.

Hackenberg, Robert A.

1995 Joe Hill Died For Your Sins. In Any Way You Cut It: Meat-Processing and Small-town America. Donald D. Stull, Michael J. Broadway, and David Griffith, eds. Pp. 232-264. Lawrence, KS: University Press of Kansas.

Hackenberg, Robert A., and Gary Kukulka

1995 Industries, Immigrants, and Illness in the New Midwest. In Any Way You Cut It: Meat-Processing and Small-town America. Donald D. Stull, Michael J. Broadway, and David Griffith, eds. Pp. 187-211. Lawrence, KS: University Press of Kansas.

Hagan, Jacqueline Maria

1994 Deciding to Be Legal: A Maya Community in Houston. Philadelphia: Temple University Press. 
Hall, Kathleen

1999 Understanding Educational Processes in an Era of Globalization: The View from Anthropology and Cultural Studies. In Issues in Education Research: Problems and Possibilities. Ellen Condliffe Lagemann and Lee S. Shulman, eds. Pp. 121-156. San Francisco: Jossey-Bass Publishers.

Hamann, Edmund T.

1995 Creating Bicultural Identities: The Role of School-Based Bilingual Paraprofessionals in Contemporary Immigrant Accommodation (Two Kansas Case Studies). Masters Thesis. University of Kansas.

1999a The Georgia Project: A Binational Attempt to Reinvent a School

District in Response to Latino Newcomers. Doctoral dissertation, University of Pennsylvania. Ann Arbor: University Microfilms.

1999b Anglo (Mis)Understandings of Latino Newcomers: A North Georgia Case Study. In Negotiating Power and Place at the Margins: Selected Papers on Refugees and Immigrants, 7. Juliene Lipson and Lucia Ann McSpadden, eds. Pp. 156-197. Washington, DC: American Anthropology Association.

Heath, Shirley Brice

1983 Ways With Words: Language, Life, and Work in Communities and Classrooms. Cambridge: Cambridge University Press.

Hernández-León, Ruben, and Victor Zuñiga

2000 'Making Carpet by the Mile:' The Emergence of a Mexican Immigrant Community in an Industrial Region of the U.S. Historic South. Social Science Quarterly 81(1):49-66.

Hinshaw, Robert, ed.

1979 Currents in Anthropology: Essays in Honor of Sol Tax. The Hague: Mouton.

Hornberger, Nancy

2000 Bilingual Education Policy and Practice in the Andes: Ideological Paradox and Intercultural Possibility. Anthropology and Education Quarterly 3 1(2) 173-201.

Hymes, Dell

1962 The Ethnography of Speaking. In Anthropology and Human Behavior. T. Gladwin and W.C. Sturtevant, eds. Pp. 13-53. Washington, DC: Anthropological Society of Washington.

1972 Introduction. In Functions of Language in the Classroom. Courtney B. Cazden, Vera P. John, and Dell Hymes, eds. New York: Teachers College Press. 
Joseph, May

1999 Nomadic Identities: The Performance of Citizenship. Minneapolis: The University of Minnesota Press.

Labaree, David F.

1997 How to Succeed in School: The Credentials Race in American Education. New Haven: Yale University Press.

Lamphere, Louise.

1992 Introduction: The Shaping of Diversity. In Structuring Diversity: Ethnographic Perspectives on the New Immigration. Louise Lamphere, ed. Pp. 1-34. Chicago: University of Chicago Press.

LeBlanc-Flores, Judith, ed.

1996 Children of La Frontera: Binational Efforts to Save Mexican Migrant and Immigrant Students. Charleston, WV: ERIC Clearinghouse on Rural Education and Small Schools.

Limón, Jose E.

1998 American Encounters: Greater Mexico, the United States, and the Erotics of Culture. Boston: Beacon Press.

Lopez-Butner, Lindy

1997 Pre-technology / Work Skills ESOL Class for At-Risk High School Students in Gwinnett County. Georgia TESOL Annual Conference. Carrolton, Georgia.

Luykx, Aurolyn

1999 The Citizen Factory: Schooling and Cultural Production in Bolivia. Albany: State University of New York Press.

Mace-Matluck, Betty J., Rosalind Alexander-Kasparik, and Robin M. Queen

1998 Through the Golden Door: Educational Approaches for Immigrant Adolescents With Limited Schooling. Washington, DC: Center for Applied Linguistics.

Mahler, Sarah J.

1998 Theoretical and Empirical Contributions Toward a Research Agenda for Transnationalism. In Transnationalism From Below. Michael Peter Smith and Luis Eduardo Guamizo, eds. Pp. 64-100. New Brunswick, NJ: Transaction Publishers.

Massey, Douglas S., Rafael Alarcón, Jorge Durand, and Humberto González

1987 Return to Aztlán: The Social Process of International Migration from Western Mexico. Berkeley: University of California Press. 
Moll, Luis C., Cathy Amanti, Deborah Neff, and Norma Gonzalez

1992 Funds of Knowledge for Teaching: Using a Qualitative Approach to Connect Homes and Classrooms. Theory Into Practice 31(1):132-141.

Moll, Luis C., and Norma Gonzalez

1997 Teachers as Social Scientists: Learning About Culture from Household Research. In Race, Ethnicity, and Multiculturalism: Policy and Practice. Peter M. Hall, ed. Pp. 89-114. New York: Garland Press. National Center for Educational Statistics

1997 The Condition of Education 1997, Supplemental Table 4-1. Electronic document, http://nces.ed.gov/pubs/ce/c9704d01.html ; accessed December 5, 2000.

Ogbu, John U.

1987 Variability in Minority School Performance: A Problem in Search of An Explanation. Anthropology \& Education Quarterly 18(4):312-334.

Olneck, Michael R.

1995 Immigrants and Education. In Handbook of Research on Multicultural Education. James A. Banks and Cheny A. McGee Banks, eds. Pp. 310-327. New York: MacMillan.

Parker, Walter C., Akira Ninomiya, and John Cogan

1999 Educating World Citizens: Toward Multinational Curriculum Development. American Educational Research Journal 36(2): 117-145.

Piore, Michael J.

1979 Birds of Passage: Migrant Labor and Industrial Societies. Cambridge: Cambridge University Press.

Powell, Arthur G., Eleanor Farrar, and David K. Cohen

1985 The Shopping Mall High School: Winners and Losers in the Educational Marketplace. Boston: Houghton Mifflin Company.

Prewitt-Diaz, Joseph O., Robert T. Trotter II, and Vidal A. Rivera

1990 The Effects of Migration on Children: An Ethnographic Study. State College, PA: Centro de Estudios Sobre la Migración.

Pugach, Marleen C.

1998 On the Border of Opportunity: Education, Community, and Language at the U.S.-Mexico Line. Mahwah, NJ: Lawrence Erlbaum Associates.

Rosaldo, Renato

1989 Culture and Truth. Boston: Beacon Press. 
Ruiz-de-Velasco, Jorge, and Michael Fix

2000 Overlooked and Underserved: Immigrant Students in U.S. Secondary Schools. Washington, DC: The Urban Institute

Sizer, Theodore R.

1984 Horace's Compromise: The Dilemma of the American High School. Boston: Houghton Mifflin.

Smith, Michael Peter

1994 Can You Imagine? Transnational Migration and the Globalization of Grassroots Politics. Social Text 39: 15-33.

Smith, Michael Peter, and Luis Eduardo Guarnizo

1998 The Locations of Transnationalism. In Transnationalism From Below. Michael Peter Smith and Luis Eduardo Guarnizo, eds. Pp. 334. New Brunswick, NJ: Transaction Publishers.

Spener, David

1988 Transitional Bilingual Education and the Socialization of Immigrants. Harvard Educational Review 58(2): 133-153.

Spindler, George

1982 Self-Appraisals: Concerns and Strategies. In Doing the Ethnography of Schooling: Educational Anthropology in Action. George Spindler, ed. Pp. 14-18. New York: Holt, Rinehart and Winston.

Spindler, George, and Louise Spindler,

1998 Cultural Politics of the White Ethniclass in the Mid-Nineties. In Ethnic Identity and Power: Cultural Contexts of Political Action in the School and Society. Yali Zou and Enrique T. Trueba, eds. Pp. 27-41. Albany: State University of New York Press.

Stark, Oded

1991 The Migration of Labor. Cambridge: Basil Blackwell. Suárez-Orozco, Marcelo M.

1998 State Terrors: Immigrants and Refugees in the Post-National Space. In Ethnic Identity and Power: Cultural Contexts of Political Action in School and Society. Yali Zou and Enrique T. Trueba, eds. Pp. 283-319. Albany: State University of New York Press.

Thomas, Wayne P., and Virginia Collier

1997 School Effectiveness for Language Minority Students. NCBE Resource Collection Series, 9. Washington: National Clearinghouse for Bilingual Education.

Tienda, Marta

1989 Looking to the 1990s: Mexican Immigration in Sociological Perspective. In Mexican Migration to the United States: Origins, Con- 
sequences, and Policy Options. Wayne A. Cornelius and Jorge A. Bustamante, eds. Pp. 109-147. San Diego, CA: Center for U.S./ Mexican Studies, University of California.

Trueba, Enrique T.

1999 The Education of Mexican Immigrant Children. In Crossings: Mexican Immigration in Interdisciplinary Perspective. Marcelo M. Suárez-Orozco, ed. Pp. 253-275. Cambridge, MA: Harvard University, David Rockefeller Center for Latin American Studies.

Tyack, David

1974 The One Best System: A History of American Urban Education. Cambridge, MA: Harvard University Press.

U.S. General Accounting Office

1994 Elementary School Children: Many Change Schools Frequently, Harming Their Education. Washington, DC: US. General Accounting Office.

Valdés, Guadalupe

1996 Con Respeto: Bridging the Distances Between Culturally Diverse Families and Schools, An Ethnographic Portrait. New York: Teachers College Press.

Vygotsky, Lev S.

1978 Mind In Society: The Development of Higher Psychological Processes. Michael Cole, V. John-Steiner, Sylvia Scribner, and E. Souberman, eds. Pp. 84-91. Cambridge: Harvard University Press.

Wong Fillmore, Lily, and Lois M. Meyer

1992 The Curriculum and Linguistic Minorities. In The Handbook of Research on Curriculum. Philip W. Jackson, ed. Pp. 626-658. New York: MacMillan Publishing Company.

Wortham, Stanton, Enrique G. Murillo, and Edmund T. Hamann, eds.

2001 Education in the New Latino Diaspora: Policy and the Politics of Identity. Westport, CT: Ablex Press.

Yeoman, Barry

2000 Hispanic Diaspora. Mother Jones, July/August: 34-41,76-77. 
Published in Negotiating Transnationalism: Selected Papers on Refugees and Immigrants, Volume IX, 2001. Edited by MaryCarol Hopkins and Nancy Wellmeier. Arlington, VA: American Anthropological Association, 2001. Pages 32-71.

A publication of the American Anthropological Association Committee on Refugees and Immigrants/General Anthropology Division.

Copyright (C) 2001 American Anthropological Association. Used by permission. 